\title{
Stable isotope analysis reveals sexual and environmental variability and individual consistency in foraging of thin-billed prions
}

\author{
Petra Quillfeldt ${ }^{1, *}$, Rona A. R. McGill ${ }^{2}$, Juan F. Masello ${ }^{1}$, Felix Weiss ${ }^{1}$, \\ Ian J. Strange ${ }^{3}$, Paul Brickle ${ }^{4}$, Robert W. Furness ${ }^{5}$
}

${ }^{1}$ Max-Planck Institut für Ornithologie, Vogelwarte Radolfzell, Schlossallee 2, 78315 Radolfzell, Germany

${ }^{2}$ Scottish Universities Environmental Research Centre, East Kilbride, Glasgow G75 0QF, UK

${ }^{3}$ New Island Conservation Trust, The Dolphins, Stanley, Falkland Islands

${ }^{4}$ Falkland Islands Government Fisheries Department, PO Box 598, Stanley, Falkland Islands

${ }^{5}$ Institute of Biomedical and Life Sciences, Graham Kerr Building, University of Glasgow, Glasgow G12 8QQ, UK

\begin{abstract}
Based on growing knowledge on the distribution of stable isotopes in marine food webs, a powerful tool to study movements and trophic position of seabirds has been developed. Here we provide an updated review of isotope studies in the Southern Ocean and use $\delta^{13} \mathrm{C}$ and $\delta^{15} \mathrm{~N}$ to evaluate diet and foraging areas of a small pelagic seabird, the thin-billed prion Pachyptila belcheri, breeding on the Falkland Islands. We found that close to egg laying, adults foraged in Falkland waters or northerly, but used more southerly foraging areas during courtship and chick rearing. Feathers grown during winter indicated that most individuals migrated south, although a small number of adults migrated north every year, consistent with regular winter observations of this species off Patagonia and southern Brazil. Thus, Antarctic waters are used regularly, but not exclusively, during the breeding and inter-breeding season. We document sex-specific segregation in foraging for the first time in this species. Males and females differed in $\delta^{13} \mathrm{C}$ and $\delta^{15} \mathrm{~N}$ during courtship and chick feeding. On average, males foraged at a higher trophic level and further north than females. The isotopic signatures of blood sampled from individual chicks at different ages were correlated, indicating consistent behaviour of adult pairs over the chick-rearing period. Analysis of differences among years revealed more depleted isotope values during warmer years, suggesting more southerly foraging and a lower trophic level diet. This agrees with previous studies suggesting that warm sea surface waters depress local food availability, forcing prions to undertake longer foraging trips further south.
\end{abstract}

KEY WORDS: Stable isotopes · Diet · Foraging area $\cdot$ Pachyptila belcheri $\cdot$ Southwest Atlantic

\section{INTRODUCTION}

Small pelagic seabirds are still difficult to follow outside of their breeding colonies, and we therefore have little knowledge of the movements and behaviour of the many species that are too small to carry devices such as satellite transmitters or data loggers. Studies of small seabirds at sea are still more restricted in species where identification from a distance is difficult, as in the prions Pachyptila spp.
Recent developments in our knowledge about the natural distribution of stable isotopes in marine food webs have provided us with a useful tool to study the movements and trophic level of seabirds, which can be applied when more direct studies are impossible (e.g. Cherel et al. 2005a, Quillfeldt et al. 2005, Bearhop et al. 2006, Cherel et al. 2006, Gladbach et al. 2007). In particular, stable carbon isotope ratios can reflect foraging locations (reviewed in Rubenstein \& Hobson 2004). Nitrogen isotope ratios become enriched in ${ }^{15} \mathrm{~N}$ by $\sim 3.0$ to 
$5.0 \%$ with trophic level increase (Minagawa \& Wada 1984 , Owens 1987$) ; \delta^{15} \mathrm{~N}$ can thus indicate trophic position and be used to infer dietary composition (e.g. Hobson \& Welch 1992, Hobson et al. 2000, Forero et al. 2005).

Following on from studies of general patterns of movement and foraging in seabird species, stable isotope ratios can now be used to explore other variables that influence ecological and behavioral patterns. For example, stable isotope ratios can help to explore differences in foraging between the sexes (e.g. Forero et al. 2005, Bearhop et al. 2006), between individuals (e.g. Nisbet et al. 2002, Cherel et al. 2006) and under different environmental conditions (e.g. Cherel et al. 2005b, Gladbach et al. 2007).

The thin-billed prion Pachyptila belcheri is a small and abundant subantarctic seabird, known to breed in 2 main areas: at Crozet and Kerguelen in the southern Indian Ocean, and on the Falkland Islands (and possibly on some islands off Tierra del Fuego; Cox 1980, Clark et al. 1984) in the southern Atlantic Ocean. New Island in the Falkland Islands is the largest known breeding site. The species' year-round distribution is poorly known because individuals are highly pelagic and mobile, and are difficult to distinguish from other species of prions when in flight. Thin-billed prions show the typical procellariiform pattern of a single-egg clutch and slow chick development, with an average fledging period of $50 \mathrm{~d}$ (Strange 1980, Quillfeldt et al. 2007a). Over $90 \%$ of their diet during the chick-rearing period consists of pelagic crustaceans (predominantly Themisto gaudichaudii and Euphausiacea), with small amounts of pelagic fish, squid, and other organisms such as salps (Strange 1980, Thompson 1989, Bocher et al. 2001, Cherel et al. 2002) also being taken. During incubation, 2 analyses at New Island found that small squid form the main part of the diet (Thompson 1989, P. Quillfeldt unpubl. data). The breeding success and provisioning rates of thin-billed prions at New Island have been analysed for the austral summers of 2002-2003 to 2004-2005 (Quillfeldt et al. 2007a). Food availability was strongly related to ocean climate, with warm waters resulting in low provisioning frequencies by thin-billed prions (Quillfeldt et al. 2007a). Of the seasons included in the present study (2003-2004 to 2005-2006), the first 2 had predominantly warm sea surface temperatures (SST) during the chick-rearing period (February SST anomalies for West Falkland waters in 2004: $0.90 \pm 0.11^{\circ} \mathrm{C}$, range 0.68 to $1.12^{\circ} \mathrm{C}_{i}$ in 2005 : $0.78 \pm 0.21^{\circ} \mathrm{C}$, range 0.17 to $1.11^{\circ} \mathrm{C}$ ), but the third season, 2006, had negative, i.e. cold, SST anomalies $(-0.42 \pm$ $0.15^{\circ} \mathrm{C}$, range -0.79 to $-0.13^{\circ} \mathrm{C}$ ).

In the present study, we apply stable isotope analysis to (1) describe patterns of movements of thin-billed prions throughout the year, (2) study sexual segregation in foraging, (3) describe patterns of individual consistency and/or variability in foraging, and (4) study the influence of SST on foraging by analyzing differences among years. Specifically, we tested the following hypotheses, based on previous knowledge of the breeding biology of thin-billed prions:

(1) Based on previous isotope studies in breeding thin-billed prions in Kerguelen suggesting the regular use of Antarctic feeding grounds (Cherel et al. 2002, 2006) and observations in winter in waters off South America, we expect seasonal movements and a range of northern and southern wintering areas.

(2) Based on the absence of sexual differences in provisioning rates (Quillfeldt et al. 2007b), we expect similar isotope values in breeding male and female birds.

(3) Based on differences in feeding rates between chicks, we expect to find consistent differences in stable isotope ratios among individual chicks.

(4) Based on previous observations that warmer waters lead to low provisioning rates (Quillfeldt et al. 2007a), we expect isotope values to reflect longer, more southerly foraging trips.

\section{MATERIALS AND METHODS}

Sample collection. Samples were collected as part of ongoing studies on the breeding biology of thin-billed prions at New Island Nature Reserve, Falkland Islands (e.g. Quillfeldt et al. 2003, 2006, 2007a,b,c). Thin-billed prions are burrow nesters, and we reached chicks and adults in their nest chambers via short access tunnels in the roof of each burrow, capped with removable stone lids. This system facilitated rapid access to chicks, reducing overall disturbance. The present study includes samples collected during 3 breeding seasons: 2003-2004 to 2005-2006. We collected the following tissues non-destructively:

Blood samples $(0.2$ to $0.4 \mathrm{ml})$ were collected after hand capture by puncturing the brachial vein in heparinised capillaries within 2 min after burrow opening. Blood samples were immediately transferred to $0.5 \mathrm{ml}$ tubes and kept on ice until centrifugation. Plasma (used for hormone analyses, e.g. Quillfeldt et al. 2006, 2007c) and blood cells (used in the present analysis) were stored frozen in separate $0.5 \mathrm{ml}$ tubes at $-20^{\circ} \mathrm{C}$.

Egg membranes were collected in the nest after hatching; clean parts were selected, removed from the eggshell and air dried. Chick down feathers start growing in the egg and continue to grow during the first 2 wk after hatching. Chick down samples were collected during the time of natural shedding of these feathers, by gently pulling a small amount of down off the tips of the contour feathers to which they were attached, and placing them in individual plastic bags. Tail feathers (rectrices of adults in 2004-2005, and undertail covert feathers in all other adults and all 
chicks) were collected by gentle pulling and placed in individual plastic bags. The first tail feathers of chicks including the tail coverts start to emerge after $3 \mathrm{wk}$ of age (e.g. Strange 1980, p. 427: 'at $22 \mathrm{~d}$ the sheaths of the rectrices can be felt protruding'); therefore, the distal parts of these feathers represent the middle of the nestling growth period of $50 \mathrm{~d}$ (i.e. about $25 \mathrm{~d}$ ). Adult moulting sequences are not well known, but mault occurs outside of the breeding season (Strange 1980).

In 2003-2004, we collected feathers of 10 chicks (down and undertail coverts) and 4 adults (found killed by Falkland skuas Catharacta antarctica or striated caracaras Phalcoboenus australis in the colony, and grown in the inter-breeding season, i.e. southern winter 2003).

In 2004-2005, we collected undertail coverts of 10 chicks and 3 blood samples from each of 8 chicks (at age 20,40 and $50 \mathrm{~d}$, the latter being 1 to $2 \mathrm{~d}$ before fledging). Seven of these 8 chicks were also sampled for feathers. Blood samples were collected from 22 adults during courtship (October 2004); from 18 of them, we also collected a single central rectrix representing the inter-breeding period, i.e. southern winter 2004. We further collected blood samples from 21 adults during chick feeding (February 2005), 6 of which had also been sampled in October 2004.

In 2005-2006, we included samples from 18 chicks, consisting of 9 samples of egg membranes, chick down samples from 13 chicks, 8 to 10 blood samples at ages 20, 40 and $50 \mathrm{~d}$, and 16 feather samples. Between 20 and $50 \mathrm{~d}$, the chick increases much in size and number of new tissues; thus, most of the 40 and 50 d samples may be represented by red blood cells (RBC) produced since the sampling at $20 \mathrm{~d}$. We were able to sample blood from only a small number of adults in the 2005-2006 season $(n=4)$ due to logistic and time constraints, but 39 feather samples were collected. Molecular sexing was carried out from blood samples or feathers as described in Quillfeldt et al. (2007b).

In February 2006, we collected 17 diet samples. Regurgitates $(n=15)$ were obtained in response to handling from adults coming in from the sea, and captured in a mistnest outside the study area. Another 2 diet samples were obtained from stomachs of 2 dead prions ( 1 adult and 1 chick). Consistent with previous studies (Strange 1980, Thompson 1989, Bocher et al. 2001, Cherel et al. 2002), these samples contained predominantly pelagic crustaceans (in order of importance: Themisto gaudichaudii, Euphausia vallentini, Munida gregaria, Calanus simillimus, larvae of Cirripedia), and 2 samples contained minor amounts of cephalopod tissue. No fish was detected in this small sample.

The Falkland Islands Fisheries Department kindly provided samples of fish (muscle of southern blue whiting Micromesistius australis, hoki Macrurounus magellanicus, pike icefish Champsocephalus esox, yellowfin rockcod Patagonotothen guntheri and Patagonian rockcod Patagonotothen ramsayi), crustaceans (whole animals of krill Euphausia lucens and Thysanoessa macrura, lobster krill Munida gregaria and amphipods Themisto gaudichaudii) and squid (muscle samples of Argentine shortfin squid Illex argentinus, great hooked squid Moroteuthis ingens and Patagonian longfin squid Loligo gahi) obtained by bottom and plankton trawling during a survey cruise close to the Falkland Islands in February 2006.

Sample preparation and stable isotope analysis. Before isotopic analysis, the lipids of fish, crustacean and squid samples, as well as regurgitates, were extracted in a Soxhlet apparatus for $6 \mathrm{~h}$ using a 2:1 chloroform:methanol mixture. Following extraction, the samples were dried under a fume hood for at least $12 \mathrm{~h}$ and ground to a homogeneous fine powder. From the regurgitates and crustaceans, we prepared 2 subsamples to account for possible effects of inorganic carbonates on ${ }^{13} \mathrm{C}$ (e.g. Pinnegar \& Polunin 1999, Carabel et al. 2006). One subsample was treated with $\mathrm{HCl}$ to remove inorganic carbonates and used to measure $\delta^{13} \mathrm{C}$. The untreated subsample was used to measure $\delta^{15} \mathrm{~N}$.

A single feather per sample and dried egg membranes were cut into small fragments using stainless steel scissors, and RBC were freeze-dried and ground. Carbon and nitrogen isotope analyses were carried out on 0.65 to $0.7 \mathrm{mg}$ aliquots of homogenized powder, weighed on tin cups.

Carbon and nitrogen isotope ratios were measured simultaneously by continuous-flow isotope ratio mass spectrometry (CF-IRMS) using a Costech Elemental Analyser (EA) linked to a Thermo Finnigan Delta Plus XP Mass Spectrometer. Two laboratory standards were analysed for every 10 unknown samples to allow correction for any instrument drift over a typical $14 \mathrm{~h}$ run. Stable isotope ratios were expressed in $\delta$ notation as parts per thousand (\%) deviations from the international standards V-Pee dee belemnite (carbon) and air (nitrogen), according to the equation $\delta X=\left[\left(R_{\text {sample }} /\right.\right.$ $\left.\left.R_{\text {standard }}\right)-1\right] \times 1000$, where $X$ is ${ }^{15} \mathrm{~N}$ or ${ }^{13} \mathrm{C}$ and $R$ is the corresponding ratio ${ }^{15} \mathrm{~N} /{ }^{14} \mathrm{~N}$ or ${ }^{13} \mathrm{C} /{ }^{12} \mathrm{C}$. Based on internal standards (tryptophan), the analytical precision $( \pm 1 \mathrm{SD})$ was estimated as \pm 0.18 and $\pm 0.17 \%$ for $\delta^{15} \mathrm{~N}$ and $\delta^{13} \mathrm{C}$, respectively.

Data analysis. For the literature survey (Appendices 1 \& 2 available at: www.int-res.com/articles/ suppl/m373p137_app.pdf), we included stable isotope data of pelagic prey species as well as seabirds and seals of the Southern Ocean, which are updated from Quillfeldt et al. (2005). Particularly for seabirds and seals, there has been a huge increase in the available information since the last review. Seals were added as a new predator group that was not previously included in the review. To analyse latitudinal variation (Fig. 1), 
we included data of samples taken during the breeding season (chick feathers, induced adult feathers and blood samples).

When comparing different tissues, tissue-dependent metabolic routing has to be taken into account. The isotope fractionation between diet and tissue was assumed to be similar to values for seabirds in the literature: RBC are very similar to whole blood (Cherel et al. 2005b): $\Delta \Delta^{13} \mathrm{C}_{\text {diet-RBC }}=1 \%, \quad \Delta^{15} \mathrm{~N}_{\text {diet-RBC }}=3 \%$ (Bearhop et al. 2002); feathers: $\Delta^{13} \mathrm{C}_{\text {diet-feathers }}=2-3 \%$ and $\Delta^{15} \mathrm{~N}_{\text {diet-feathers }}=4-5 \%$ (Mizutani et al. 1992, Bearhop et al. 2002). The isotope fractionation between diet and egg shell membranes for a range of terrestrial birds was $\Delta{ }^{13} \mathrm{C}_{\text {diet-egg membrane }}=3 \%$ and $\Delta \Delta^{15} \mathrm{~N}_{\text {diet-egg membrane }}=4 \%$ (Hobson 1995). Thus, blood is generally less enriched in the heavier isotopes of both carbon and nitrogen compared to feathers, while discrimination factors for feathers and egg membranes are in the same range.

We compared stable isotope ratios in simultaneously grown feathers and blood cells in thin-billed prion chicks $(n=17)$. The values for feathers and RBC were highly correlated (carbon: $\mathrm{r}=0.912, \mathrm{p}<0.001$; nitrogen: $\mathrm{r}=0.859, \mathrm{p}<0.001$ ), allowing us to calculate correction factors to compare both tissue types. We found the following pairwise differences that were used as correction factors: carbon: $0.9 \pm 0.1 \%, t=13.9, \mathrm{p}<0.001$; nitrogen: $0.3 \pm 0.1 \%, t=2.5, \mathrm{p}=0.021)$. We corrected blood cell stable isotope data by adding the correction factor, before comparing with other tissues (see Figs. 2 $\& 7$ and ANOVA among chick ages). Data analysis was carried out using SPSS 11.0. We checked for deviations from normality with Kolmogorov-Smirnov tests. All samples except those of adult feathers were normally distributed. For adult feather isotope data, we thus used nonparametric tests. For all other (normally distributed)

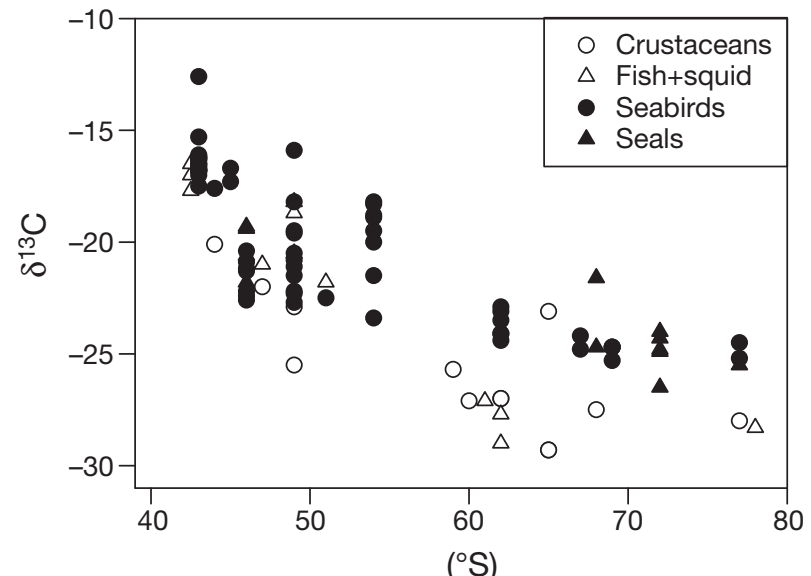

Fig. 1. Variation in the stable carbon isotope ratios in seabirds and pelagic prey types in the Southern Ocean (see Appendices 1 \& 2 available at: www.int-res.com/articles/suppl/ m373p137_app.pdf for data and sources) samples, isotopic signatures were compared among groups using discriminant analysis (Wilk's $\lambda$ ). If overall differences were detected, $\delta^{15} \mathrm{~N}$ and $\delta^{13} \mathrm{C}$ values were compared separately by 1 -way ANOVA or $t$-tests as appropriate. For tests of dietary consistency of individual chicks, we correlated the different sample types of each individual (eggs, feathers and blood samples at different ages) using Pearson correlations. We ran general linear models (GLM) that controlled for interannual effects by including year as a categorical independent variable ('factor'), but as these did not alter the results, we report the statistical results for the Pearson correlations. Significance was assumed at $\mathrm{p}<0.05$, and means are given with standard errors.

\section{RESULTS}

\section{Data overview and comparison with potential diet}

A literature survey (see Appendices $1 \& 2$ for data) showed a marked decrease in stable carbon isotope ratios of pelagic prey species as well as seabirds and seals of the Southern Ocean with latitude (Fig. 1; only breeding season data included), the more southerly species having lower carbon isotope ratios.

Fish, squid and crustaceans collected in the vicinity of the Falkland Islands had distinct isotopic signatures (Fig. 2; Wilk's $\lambda=0.31, \mathrm{p}<0.001$ ). Differences among the

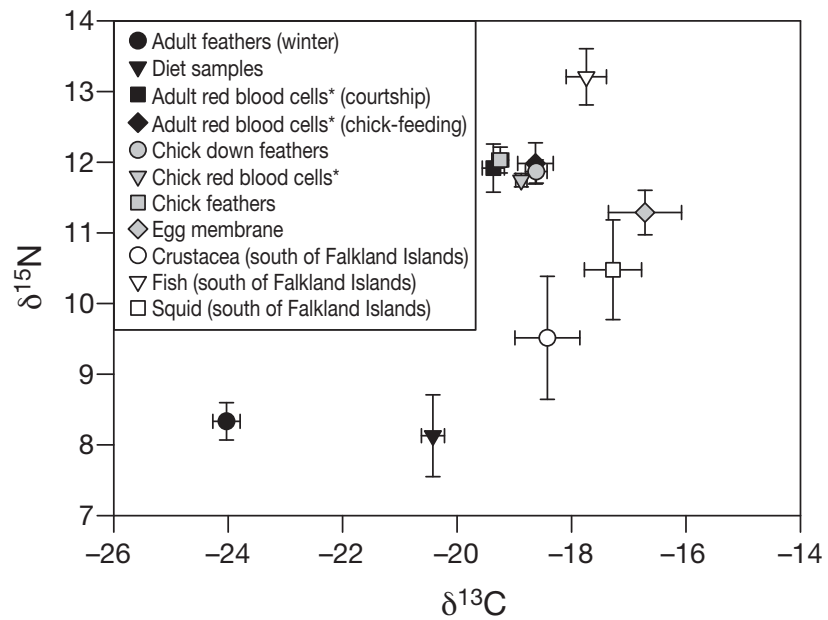

Fig. 2. Pachyptila belcheri. Stable carbon and nitrogen isotope signatures (means $\pm \mathrm{SE}$ ) of samples taken at the breeding colony on New Island, Falkland Islands $\left(51^{\circ} 43^{\prime} \mathrm{S}\right.$, $\left.61^{\circ} 17^{\prime} \mathrm{W}\right)$, in comparison with marine samples taken in nearby waters. Fish, crustacean and squid samples were collected south of the Falkland Islands $\left(\sim 52^{\circ} \mathrm{S}\right)$ by the Falkland Islands Government Fisheries department. $\left({ }^{*}\right)$ Red blood cells from adults sampled during courtship (October) and during the chick-feeding period (January to February); chick red blood cells were corrected to account for different diet-tissue fractionation and make the data comparable. Correction factors were 0.9 and $0.3 \%$ for carbon and nitrogen, respectively 
3 groups were strongest in $\delta^{15} \mathrm{~N}$ values (ANOVA: $F_{34,2}=$ $22.4, \mathrm{p}<0.001$ ), where all pairwise comparisons (Tukey's post-hoc tests) were significant. There was also an overall difference between fish, squid and crustaceans in $\delta^{13} \mathrm{C}$ values (ANOVA: $F_{34,2}=5.5, \mathrm{p}=0.008$ ), but only crustaceans were statistically distinct from squid and fish, which had similar $\delta^{13} \mathrm{C}$ (Tukey's post-hoc tests).

Compared with fish, squid and crustaceans collected in the vicinity of the Falkland Islands, samples of different tissues of thin-billed prions had a wide range of isotopic signatures, especially in $\delta^{13} \mathrm{C}$ (Fig. 2). The $\delta^{13} \mathrm{C}$ of thin-billed prion egg membranes, after correction for collagen enrichment, were consistent with foraging grounds in the vicinity of the Falkland Islands, while all other samples had smaller $\delta^{13} \mathrm{C}$ than crustaceans collected close to the islands, suggesting more southerly foraging areas. Tissue carbon isotope ratios (with the exception of egg membranes) were consistent with the observation of lower carbon isotope values for diet samples collected from regurgitates during the chickrearing period, compared with fresh crustaceans caught close to the islands (Fig. 2). The mean $\delta^{13} \mathrm{C}$ of diet samples was $-20.5 \pm 0.2 \%$, thus $\sim 2 \%$ lower than the mean $\delta^{13} \mathrm{C}$ of crustaceans caught close to the islands $(-18.5 \pm 0.4 \%$; Wilk's $\lambda=0.59, \mathrm{p}<0.001)$.

\section{Feathers grown during the breeding and inter-breeding periods}

Feathers of adults (grown in the inter-breeding season) and chicks (grown in the breeding season) differed in their isotopic signatures (Fig. 3). Adult feathers had a much wider range (Fig. 3a), with most feathers showing low isotope values in both carbon (mean $\delta^{13} \mathrm{C}$ of adults $-22.3 \pm 0.3 \%$, range -28.1 to $-18.3 \%$; chicks $-19.2 \pm 0.2 \%$, range -22.3 to $-17.4 \%$; Mann-Whitney $U_{36,61}=100, \mathrm{p}<0.001$ ) and nitrogen (Fig. $3 \mathrm{~b}$; mean $\delta^{15} \mathrm{~N}$ of adults $9.3 \pm 0.2 \%$, range 5.9 to $17.0 \%$; chicks $12.2 \pm 0.2 \%$, range 10.1 to $13.7 \%$; Mann-Whitney $\left.U_{36,61}=131, \mathrm{p}<0.001\right)$.

While $80 \%$ of the adult feathers had values in the range of -25.5 to $-23.0 \%$ for $\delta^{13} \mathrm{C}$ and 6 to $8 \%$ for $\delta^{15} \mathrm{~N}$, some adults had very different values. In all years, a small number of adults had considerably higher isotope ratios than the average (up to $6 \%$ for carbon and $8 \%$ for nitrogen), while some feathers grown in the southern winter of 2005 had lower (by 2 to $3 \%$ ) carbon isotope ratios. Among adult feathers, we did not detect differences in isotope ratios between inter-breeding seasons (Fig. 3a; Kruskal Wallis test for carbon: $\chi^{2}=4.4$, $\mathrm{df}=2, \mathrm{p}=0.111$; for nitrogen: $\chi^{2}=5.1, \mathrm{df}=2, \mathrm{p}=0.077$, or between feathers of male and female adults (carbon: Mann-Whitney $U_{20,33}=323, \mathrm{p}=0.891$; nitrogen: MannWhitney $U_{20,33}=308, \mathrm{p}=0.680$ ).
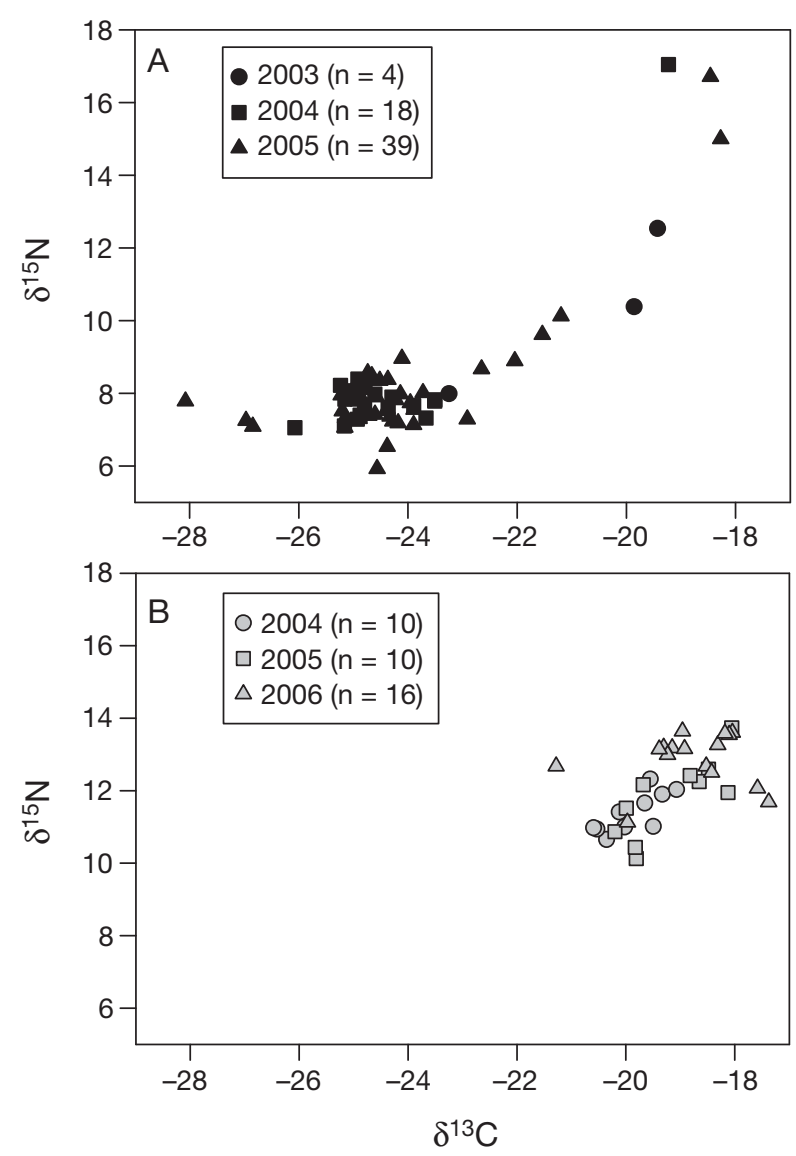

Fig. 3. Pachyptila belcheri. Stable isotope signatures of feathers of adults and nestlings. One feather per bird was analysed, so each data point represents 1 individual. The feathers were collected over 3 breeding seasons from 2003-2004 to 2005-2006. (A) Adult feathers (rectrices or undertail coverts) represent the inter-breeding season when the feathers were grown, and (B) chick feathers (undertail coverts) were grown towards the end of the breeding season, i.e. late February to early March

Chick feathers differed in isotope values between years (Fig. 3b; Wilk's $\lambda=0.55, \mathrm{p}=0.001$ ), for carbon (ANOVA: $F_{2,33}=5.2, \mathrm{p}=0.011$; Tukey's post-hoc tests: 2004 vs. $2005: \mathrm{p}=0.151,2004$ vs. $2006: \mathrm{p}=0.008,2005$ vs. 2006: $\mathrm{p}=0.517$ ) and nitrogen (ANOVA: $F_{2,33}=11.8$, $\mathrm{p}<0.001$; Tukey's post-hoc tests: 2004 vs. 2005: $\mathrm{p}=$ 0.485, 2004 vs. $2006: \mathrm{p}<0.001,2005$ vs. 2006: $\mathrm{p}=$ 0.007 ). Thus, feathers sampled in 2004 had lower average isotope values than those sampled in 2006 (Fig. 3b).

\section{Blood samples of adults and chicks - seasonal effects and individual consistency}

Consistent with results for the feather samples, RBC samples from chicks also indicated differences in iso- 
tope ratios between years (Fig. 4 ; Wilk's $\lambda=0.55, \mathrm{p}=$ $0.011)$, particularly in nitrogen isotope values $(t=3.5$, $\mathrm{df}=16, \mathrm{p}=0.003$ ), while carbon isotope values did not differ $(t=1.6, \mathrm{df}=16, \mathrm{p}=0.126)$.

While RBC samples of adults taken during the breeding season fit this picture well (see Fig. 4), there were too few samples in 2006 to allow statistical comparison between years. The isotope ratios of $\mathrm{RBC}$ of nestling and adult thin-billed prions collected during the chick-rearing period of 2005 were not statistically separated (Fig. 4; Wilk's $\lambda=0.81, \mathrm{p}=0.061$ ).

There is a 2 to $2.5 \%$ range in carbon isotope values for chick blood samples at each sampled stage (Fig. 5a), which may reflect heterogeneity of feeding habits between individuals. However, individual dietary consistency is implied by the smaller variance between individual chick samples taken at different times during the nestling period, than across the whole group: the isotope ratios of chick blood cells at $20 \mathrm{~d}$ of age strongly predicted the isotope ratios of chick blood cells at 40 and $50 \mathrm{~d}$ of age (e.g. carbon at 20 vs. $40 \mathrm{~d}$ old: $R_{16}=0.82, \mathrm{p}<0.001$, nitrogen at 20 vs. $40 \mathrm{~d}$ old: $\left.R_{16}=0.83, \mathrm{p}<0.001\right)$.

In adults, we did not find evidence for individual consistency in isotope ratios over different periods of the year, as neither winter (feather) and spring (RBC) values nor spring and summer (RBC) values were correlated (all pairwise correlations $\mathrm{p}>0.2$ ).

Females had lower carbon and nitrogen isotope values in $\mathrm{RBC}$ than males during the chick-feeding period (Fig. 6 ; courtship: Wilk's $\lambda=0.91, \mathrm{p}=0.398$; chick-feeding: Wilk's $\lambda=0.67, \mathrm{p}=0.035)$. The $\delta^{13} \mathrm{C}$ in $\mathrm{RBC}$ of adults differed between the courtship and the chick-

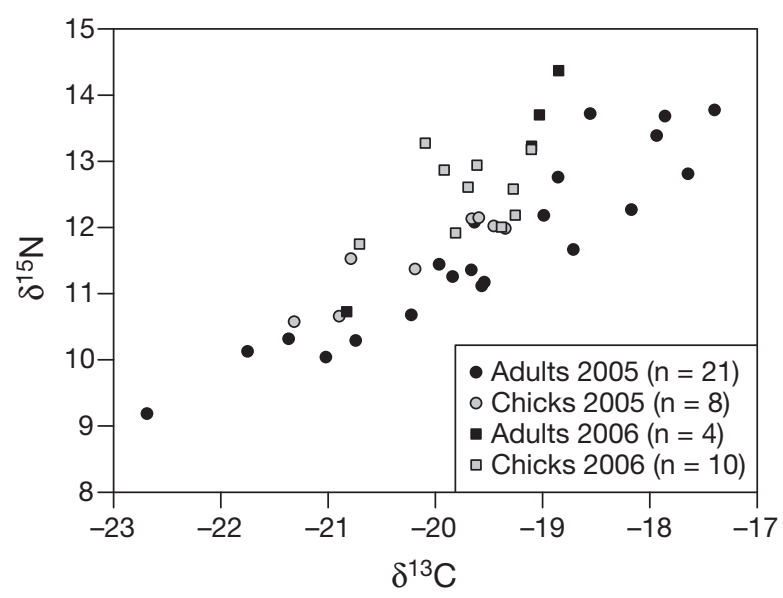

Fig. 4. Pachyptila belcheri. Stable carbon and nitrogen isotope signatures of red blood cells of nestlings and adults in 2 seasons. We included only adult samples collected during the chick-rearing period (February) and chick samples taken during the same month, at $40 \mathrm{~d}$ of age
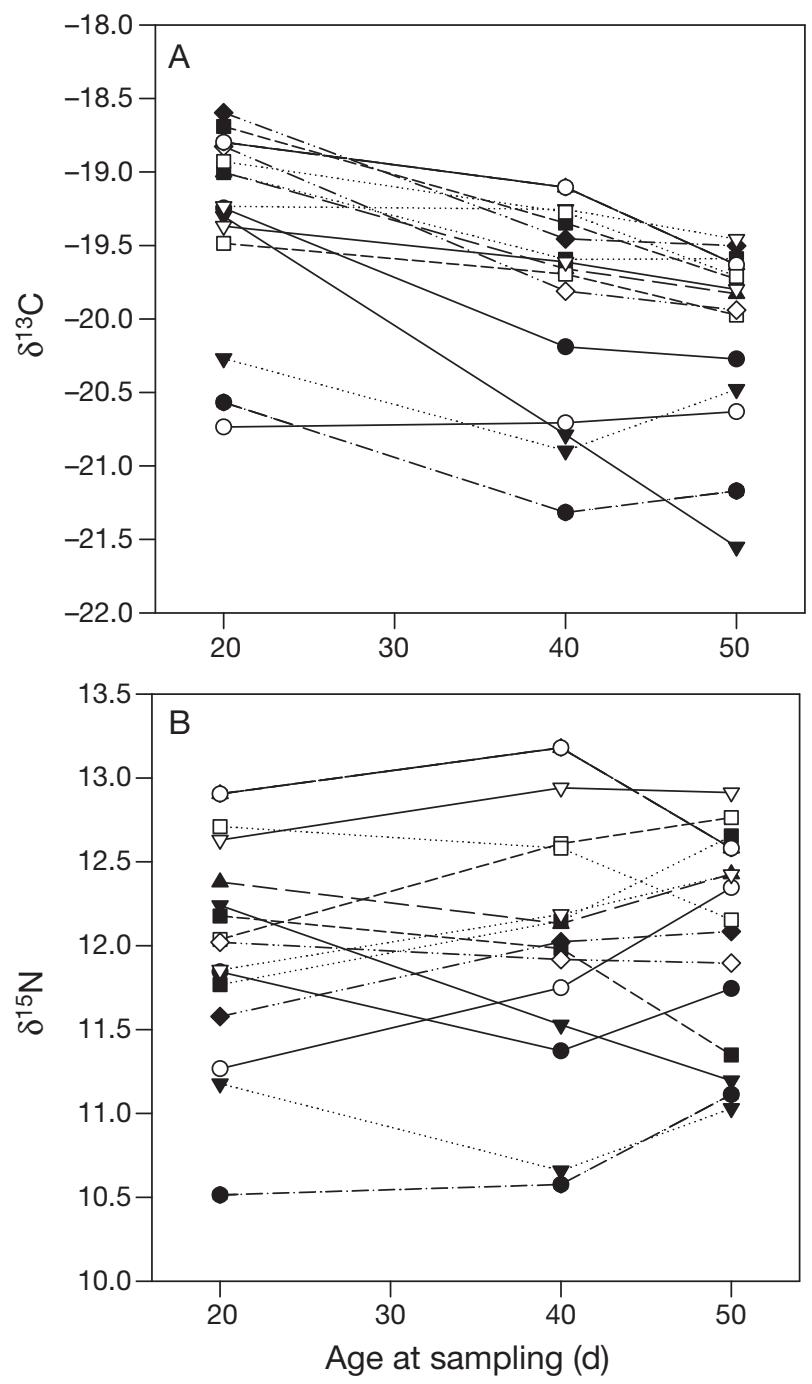

Fig. 5. Pachyptila belcheri. (A) Carbon, and (B) nitrogen stable isotope ratios of red blood cells of individual chicks sampled 3 times during their nestling period. White symbols are chicks sampled in 2005; black symbols are chicks from the 2006 breeding season

feeding period (Fig. 6) and less strongly between the sexes (Table 1), while there was a sex effect only in $\delta^{15} \mathrm{~N}$, without seasonal variation (Table 1).

\section{Samples of eggs and chicks}

We compared a sequence of samples reflecting subsequent stages of chick development: egg (membrane), chick down feathers, chick feathers and chick blood samples (Figs. $2 \& 7$ ), using corrected values for blood (see 'Materials and methods - Data analysis'). The sequence indicated a gradual shift in foraging areas 


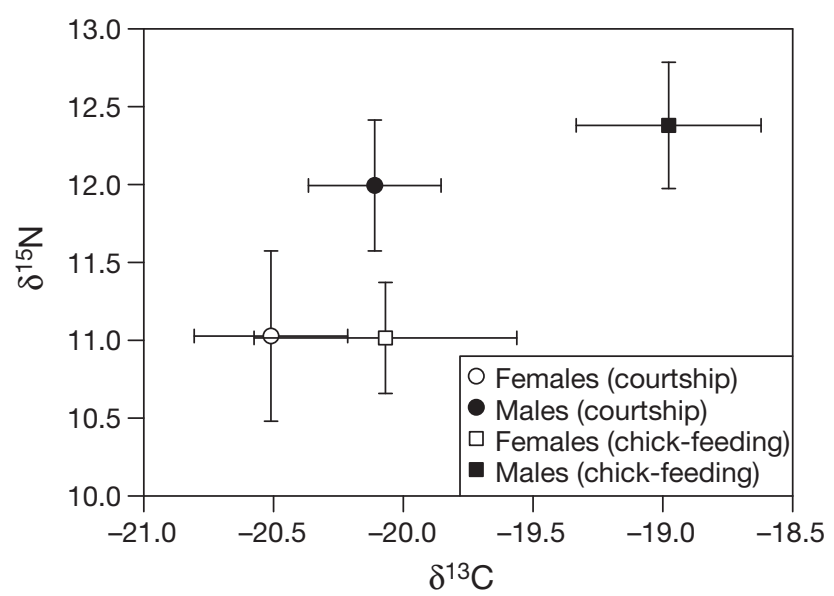

Fig. 6. Pachyptila belcheri. Stable isotope signatures (means \pm SE) of adult red blood cells during the 2004-2005 breeding season, separated by sex and phase in the breeding cycle

Table 1. Pachyptila belcheri. Differences in carbon and nitrogen stable isotope ratios (measured in red blood cells of adults) between sexes and phases of the breeding season (courtship vs. chick feeding) in the 2004-2005 breeding season, tested using the generalised linear model (GLM). Interactions were initially included in the models, but subsequently removed as they were found to be insignificant

\begin{tabular}{|c|c|c|c|c|c|c|}
\hline Source & $\begin{array}{l}\text { Type III sum } \\
\text { of squares }\end{array}$ & $\mathrm{df}$ & $\begin{array}{l}\text { Mean } \\
\text { square }\end{array}$ & $F$ & $\mathrm{p}$ & $\chi^{2}$ \\
\hline \multicolumn{7}{|l|}{$\delta^{13} \mathrm{C}$} \\
\hline Sex & 5.6 & 1 & 5.6 & 4.1 & 0.048 & 0.094 \\
\hline Season & 7.2 & 1 & 7.2 & 5.3 & 0.026 & 0.117 \\
\hline Error & 53.9 & 40 & 1.3 & & & \\
\hline Total & 65.3 & 42 & & & & \\
\hline \multicolumn{7}{|l|}{$\delta^{15} \mathrm{~N}$} \\
\hline Sex & 14.0 & 1 & 14.0 & 7.0 & 0.012 & 0.149 \\
\hline Season & 0.5 & 1 & 0.5 & 0.2 & 0.636 & 0.006 \\
\hline Error & 80.4 & 40 & 2.0 & & & \\
\hline Total & 94.5 & 42 & & & & \\
\hline
\end{tabular}

from north to south as the season progressed, indicated by decreasing $\delta^{13} \mathrm{C}$ (Fig. 7 ; ANOVA: $F_{107,5}=13.5, \mathrm{p}<$ 0.001; Tukey's posthoc test separated egg membranes from the remaining groups). The down feathers had intermediate values between those of eggs and feathers, although the difference between down feathers and feathers was not significant (Tukey's posthoc test $\mathrm{p}=0.066$; Fig.7). The $\delta^{15} \mathrm{~N}$ values of egg membranes were low compared to all other groups (Fig. 7; ANOVA $F_{107,5}=2.8, \mathrm{p}=0.019 ;$ Tukey's posthoc test separated egg membranes from the remaining groups). The $\delta^{15} \mathrm{~N}$ of down feathers and tail covert feathers of individual chicks were correlated (2004 and 2006 combined; $R_{21}=$ $0.71, \mathrm{p}<0.001)$, but not the $\delta^{13} \mathrm{C}\left(R_{21}=0.14, \mathrm{p}=0.534\right)$.

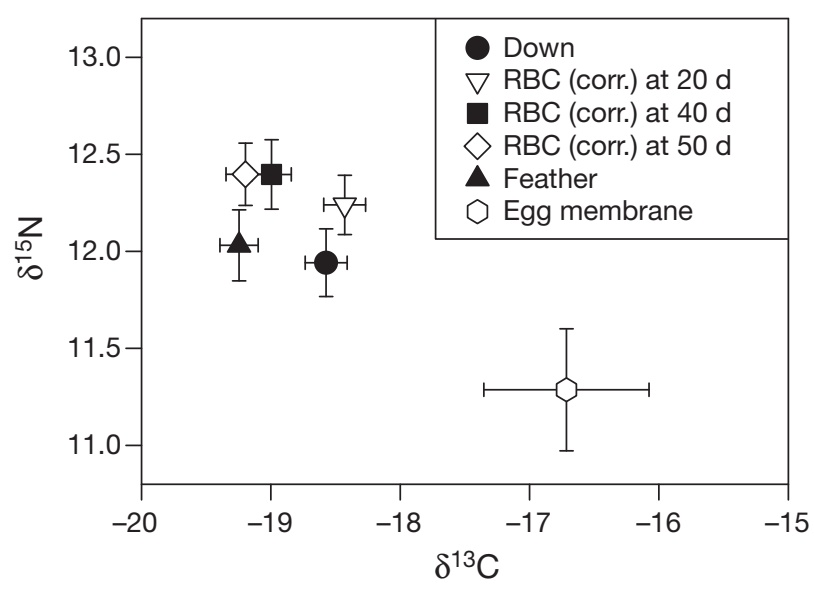

Fig. 7. Pachyptila belcheri. Stable isotope signatures (means \pm $\mathrm{SE}$ ) of egg membranes, feathers (down and undertail coverts) and red blood cells (RBC) collected at different nestling ages over the breeding season. Stable isotope data of RBC were corrected to account for different diet-tissue fractionation and make the data comparable. Correction factors were 0.9 and $0.3 \%$ for carbon and nitrogen, respectively

\section{DISCUSSION}

Altered by a small reproducible fractionation value, animal tissues reflect the isotopic signature present in food; thus, it is possible to use stable isotope ratios to examine patterns of diet and migration (e.g. review by Hobson 1999). Here, we applied this approach to a small pelagic seabird, the thin-billed prion.

\section{Breeding season distribution}

As in previous studies (Quillfeldt et al. 2005, Cherel \& Hobson 2007), recent data collated from the literature indicated a marked decrease in stable carbon isotope ratios in Southern Ocean predators with latitude (Appendices $1 \&$ 2, Fig. 1). This geographic variation (Fig. 1) was found despite the potentially confounding effects of pelagic species and different tissues (whole blood, blood cells and feathers) included in the analysis.

We therefore used $\delta^{13} \mathrm{C}$ of regurgitated diet samples, $\mathrm{RBC}$, egg membranes and feathers to investigate shifts in foraging areas within and between seasons. Thinbilled prions feed nearly exclusively on pelagic prey; thus, any confounding effects of benthic-pelagic gradients in $\delta^{13} \mathrm{C}$ should be minor. Compared with fish, squid and crustaceans collected in the vicinity of the Falkland Islands, samples of different tissues of thinbilled prions had a very wide range of isotopic values, especially in $\delta^{13} \mathrm{C}$. The samples collected earliest in the breeding season were RBC from adult birds during the 
courtship period, in October 2004. During this period, adults had lower $\delta^{13} \mathrm{C}$ values (implying more southerly feeding areas) than later on, during the chick-feeding period (Table 1, Fig. 6).

The highest $\delta^{13} \mathrm{C}$ values were found in egg membranes (potentially from resources consumed in an intermediate period), suggesting that close to egg laying, female thin-billed prions foraged in or north of the Falkland Islands. High ${ }^{13} \mathrm{C}$ values may result from egg membranes consisting mainly of collagen, a protein enriched in ${ }^{13} \mathrm{C}$. However, literature data suggest that egg membrane isotope discrimination factors are similar to those of feathers (Hobson 1995). Using 2 abandoned thin-billed prion eggs, we compared albumen and egg membrane and found a very small enrichment in the membrane of 0.20 and $1.07 \%$. Thus, despite correction for the enrichment, membranes indicated northerly foraging during egg formation, compared with southerly foraging during the chick-feeding period.

A second possible enrichment source may be the use of internal resources to form the egg. However, a study on moulting penguins (Cherel et al. 2005b) suggested that this process would lead to $\sim 0.4 \%$ enrichment of $\delta^{13} \mathrm{C}$, which is less than expected for normal diettissue fractionation and could not explain the higher values observed here.

Thus, the most likely explanation would be that females find areas of high productivity close to or north of the Falkland Islands during egg production (honeymoon flight). Two independent analyses of the diet of thin-billed prions at New Island during incubation found mainly small squid (Thompson 1989, P. Quillfeldt unpubl. data). In contrast, studies carried out during chick feeding consistently reported $>90 \%$ crustaceans in the diet (Strange 1980, Thompson 1989, Bocher et al. 2001, Cherel et al. 2002). Thus, there is strong indication of a diet switch from conventional data, which is matched by the present isotope data.

It is also unlikely that metabolic processes would result in artificial enrichment of carbon or nitrogen isotope values for egg tissues, because in another procellariiform species, Wilson's storm-petrels Oceanites oceanicus, eggs showed the opposite trend, indicating a southern honeymoon flight distribution (Gladbach et al. 2007). As in that study, we found that chick down had intermediate values between the stable carbon and nitrogen isotope ratios measured in eggs and chick feathers. Intermediate values for both $\delta^{13} \mathrm{C}$ and $\delta^{15} \mathrm{~N}$ indicate that down is grown from a mixture of maternal resources from the egg, and nutrients in the post-hatching diet (Gladbach et al. 2007).

In contrast to egg membranes, the samples of feathers and blood of all age groups and periods had smaller $\delta^{13} \mathrm{C}$, on average, than crustaceans collected close to the islands, suggesting more southerly foraging areas. Similarly, the mean $\delta^{13} \mathrm{C}$ of diet samples was $\sim 2 \%$ lower than the mean $\delta^{13} \mathrm{C}$ of crustaceans caught close to the islands. Thus, the present data suggest that the birds moved between the islands and southern foraging areas during courtship as well as chick rearing. Foraging in southern waters is also supported by the presence of Euphausia superba in the stomach content of breeding birds from the Kerguelen Islands (Cherel et al. 2006). Large numbers of thinbilled prions have also been reported over the Patagonian shelf and in the vicinity of the Falkland Islands during the summer (Strange 1980, White et al. 1999). These observations are consistent with the isotope data, as thin-billed prions use both long and short foraging trips during the breeding season (Quillfeldt et al. 2007b). During short trips, they probably stay in the vicinity of the Falkland Islands, while long trips of up to $8 \mathrm{~d}$ (Quillfeldt et al. 2007b) might take them to areas south of the Subantarctic Front. This would explain why blood samples and chick feathers collected during the breeding season have intermediate values, relative to the southern wintering areas and the Falkland data.

Cherel et al. (2002) found that chicks and adults of thin-billed prions from Kerguelen showed similarly low carbon isotopic values in feathers, suggesting no major changes in the trophic position or foraging areas of the birds between the moulting period of the chicks (breeding period) and the moulting period of adults (inter-breeding period). In the present study, we contrastingly found differences between chick and adult feathers in carbon and nitrogen isotope ratios. Carbon isotope ratio variations may reflect a difference in foraging areas, and the differences in nitrogen isotope ratio may be due to lower values for the base of the food web in the Antarctic (e.g. Fig. 1; Quillfeldt et al. 2005, Cherel \& Hobson 2007).

\section{Wintering distribution}

The present data from adult feathers grown during winter indicate that most individuals migrated south during the inter-breeding period, but that every year, a small number of adults spent the inter-breeding period in a more northern foraging area.

Pachyptila spp. range over wide areas of ocean and are difficult to distinguish in flight, which makes direct observations of their species' distributions nearly impossible. Information based on observations of thin-billed prions, for example, is limited to general descriptions such as 'disperses widely over Southern Ocean after breeding' (Carboneras 1992), and observations such as 'birds from the Falklands apparently 
move $\mathrm{W}$, gathering in large flocks off W South America, and ranging $\mathrm{N}$ to $15^{\circ} \mathrm{S}$; Indian Ocean birds move E, occurring regularly off Australia and New Zealand, but few records off S Africa' (Carboneras 1992). This information is neither consistent with regular observations of wintering flocks off the coast of Brazil (e.g Neves et al. 2006), nor with recent data on stable isotopes, suggesting that thin-billed prions moult in Antarctic waters (Cherel et al. 2002, 2006). White et al. (1999) noted very low densities of thin-billed prions in Falkland Island waters from March to May. This would be explained by migration into Antarctic waters during moulting as indicated by the low $\delta^{13} \mathrm{C}$ values of feathers grown in winter, which is best comparable to birds breeding in the South Shetland Islands $\left(62^{\circ} \mathrm{S}\right.$, Fig. 1; Quillfeldt et al. 2005). Thinbilled prions from the Kerguelen Islands showed similarly low $\delta^{13} \mathrm{C}$ values (Cherel et al. 2006). A long-term study on the breeding performance and adult survival in the Kerguelen Islands found a negative correlation between the survival of adult thin-billed prions and sea ice cover in the Antarctic (Nevoux \& Barbraud 2006), which is consistent with the proposed moulting area. The species was not noted during ship-based studies on seabird abundance in the Scotia or Weddell Sea (Ainley et al. 1993, 1994), but it is possible that they were confused with the similar Antarctic prion Pachyptila desolata, which feeds further north in winter according to their isotope signatures (Cherel et al. 2002, 2006).

Although exhibiting low average carbon isotope values, feathers of adult thin-billed prions showed wide variation in $\delta^{13} \mathrm{C}$ values, ranging over $9.6 \%$. This cannot be explained by feeding at different trophic levels, as the enrichment is only likely to be $\sim 0.4 \%$ for each level (e.g. Post 2002). In contrast, we observed rather uniform $\delta^{13} \mathrm{C}$ values in the blood of adult birds during the breeding season. The data therefore suggest that some individuals spent the winter moult in more northerly areas, consistent with regular observations of wintering flocks off the coast of Brazil (e.g. Neves et al. 2006). These more northern areas might be located over the Patagonian shelf or along the shelf break. The blood carbon isotope values of seabirds at the Argentinian coast ranged between -12.6 and $-17.5 \%$ (Forero et al. 2004), and are thus higher than the high (northern) values observed for prions. As more pelagic prey have depleted stable carbon isotope ratios, it seems likely that the northern distribution is found close to the nutrient-rich areas along the shelf edge, as also suggested by the data in Neves et al. (2006) for the wintering distribution in southern Brazil. Such divergent patterns in the moult strategy within a population has also been described for common diving petrels Pelecanoides urinatrix at the Kerguelen Islands, but were not found in thin-billed prions breeding on the Kerguelen Islands or common diving petrels breeding on South Georgia (Cherel et al. 2006).

To date, little or no stable isotope data is available from the other proposed thin-billed prion wintering area off W South America (e.g. Carboneras 1992). Recent data from the Humboldt current at $36^{\circ} \mathrm{S}$ (Hückstädt et al. 2007) suggest that we can exclude this area for the birds in the present analysis, because the $\delta^{13} \mathrm{C}$ data of the pelagic prey and small fish were outside of the range observed here, i.e. Humboldt krill Euphausia mucronata: $\delta^{13} \mathrm{C}=-16.0 \%$, anchovy Engraulis ringens: $\delta^{13} \mathrm{C}=-15.6 \%$, and herring Strangomera bentincki: $\delta^{13} \mathrm{C}=-14.7 \%$ (Hückstädt et al. 2007).

\section{Sexual segregation}

Stable isotope ratios can be used to explore differences in foraging between the sexes (e.g. Forero et al. 2005, Bearhop et al. 2006). Sexual differences in the diet and distribution of thin-billed prions have not, to our knowledge, been previously investigated. The sexes differed in $\delta^{13} \mathrm{C}$ values, with males exhibiting higher carbon isotope ratios, indicating a tendency to forage further north. This sexual difference was especially pronounced during the chick-feeding period (Table 1, Fig. 6). The $\delta^{15} \mathrm{~N}$ values of RBC from adult thin-billed prions during the courtship period as well as during the chick-feeding period also indicate a sexual difference in the diet consumed (Table 1, Fig. 6), with females feeding at a lower trophic level than males. The difference of 1 to $1.5 \%$ in $\delta^{15} \mathrm{~N}$ (i.e. $<1$ trophic level) suggests that the variation comes from differences in the relative amounts of different diet types taken, and is in the same range as that recorded for southern giant petrels Macronectes giganteus (Forero et al. 2005). The discrepancy in values between the sexes is similar to a finding in several species of diving seabirds from South Georgia and Kerguelen (Bearhop et al. 2006), in which males consistently foraged at a higher trophic level than females.

Compared to adult values, a smaller range in carbon and nitrogen isotope ratios was found from chick samples, which most likely reflects biparental care; each chick integrates the diet of 2 adults; thus, more extreme northerly or southerly foraging by one parent can only partially influence the chicks' diet.

There were no differences in stable isotope signatures of feathers between male and female adults, but this may be due to the large variance in the data and the small sample size (e.g. $\mathrm{n}=4$ in 2003). A larger dataset is required to analyse possible sexual segregation during the inter-breeding period. 


\section{Individual consistency}

Stable isotope analysis can also be used to describe differences between individuals (e.g. Nisbet et al. 2002, Bearhop et al. 2006, Cherel et al. 2006), which may indicate foraging specialisation, based on individual abilities or experience. This is usually done by sampling tissues that integrate long periods, different tissues from each individual, tissues that are produced at different times, or tissues that have different turnover rates. Here, we use RBC of chicks collected at different ages. Between the sampling points at $20 \mathrm{~d}$ and at 40 to $50 \mathrm{~d}$, chicks added much new tissue, including new blood cells. Any older RBC would also have experienced considerable isotopic turnover. The half-life of isotope turnover for avian RBC was $29.8 \mathrm{~d}$ in crows Corvus brachyrhynchos (Hobson \& Clark 1993) and 10.9 d for yellow-rumped warblers Dendroica coronata (Podlesak et al. 2005). The RBC samples collected from thin-billed prion chicks therefore represented the diet ingested ca. 2 to 4 wk before the sampling.

We found evidence for consistent behaviour of adult pairs over the course of the chick-rearing period, as the carbon and nitrogen isotopic values of blood samples taken from individual chicks at different ages (20 to $50 \mathrm{~d}$ of age) were correlated. In addition, the nitrogen isotope composition of down feathers and tail covert feathers of individual chicks were correlated.

In adults, we did not find evidence for individual consistency in carbon or nitrogen isotope ratios over different periods of the year, as neither winter (feather) and spring (RBC) values nor spring and summer (RBC) values were correlated (all pairwise correlations $\mathrm{p}>0.2$ ). With the present dataset, it was not possible to test for individual consistency over shorter periods during the breeding season, or over several breeding seasons. The latter will require sampling the same adults in different seasons, and would indicate whether likely 'northern' and 'southern' winter migrating subpopulations exist.

\section{Interannual variability}

In addition to providing general patterns of foraging in seabirds, stable isotope ratios have recently been applied to document behavioural patterns caused by additional variables, such as differing environmental conditions. For example, stable carbon isotope analyses of feathers of adult Wilson's storm-petrels showed that the birds wintered further north during a cold year in the South Atlantic, when frontal systems that are rich in primary and secondary production were found at more northerly latitudes (Gladbach et al. 2007).
In the present study, 2 breeding seasons (2004 and 2005) were characterised by warm sea surface waters, and the corresponding $\delta^{13} \mathrm{C}$ values of chick feathers indicated more southerly foraging areas than in a third, colder, year (2006: see 'Introduction' for temperature means and ranges). Carbon isotope compositions of chick feathers reflected the changes in environmental conditions remarkably well. In 2004 when the highest SSTA (sea surface temperature anomaly) was noted, feathers had the lowest carbon isotope values. In 2005 when the largest variability in SSTA was observed, the range in isotope data was also widest, and the highest carbon isotope ratios were observed in 2006, the year with the coldest water. This is consistent with previous studies of thin-billed prions (Quillfeldt et al. 2007a), suggesting that warm sea surface waters depress local food availability, forcing prions to forage further south and undertake longer foraging trips.

Consistent with the feather samples, the RBC samples of chicks also exhibited differences in carbon and nitrogen isotope ratios between years, while no differences in isotope ratios for adult feathers grown during inter-breeding seasons were detected. This may be due to the large variance in the isotope values obtained for all inter-breeding seasons. In all years, some adults had anomalously high carbon and nitrogen isotope ratios, while a small number of feathers grown in the southern winter of 2005 had lower isotope ratios, suggesting even more southerly foraging areas than in most birds.

Following on from the present results, additional data are required to determine the different winter and summer feeding areas of individual birds, and whether these are consistent between seasons. The foraging patterns of nonbreeders could also be valuable in our understanding of this species, and a larger dataset of chick tissues could be used to investigate if individual carbon and nitrogen isotope values can be correlated with physical parameters such as body condition, peak and fledging mass. In addition, samples of the potential prey species from years that differ in conditions are required to evaluate possible changes in baseline isotope ratios of lower trophic levels between years.

Acknowledgements. We thank the New Island Conservation Trust for permission to work on the island and for providing accommodation and transport. NERC funded the isotope analysis. We also thank M. Strange and V. Roesch for contributions to this work; G. Segelbacher for doing molecular sex determination at the University of Freiburg, assisted by H. van Noordwijk; Y. Cherel and R. Phillips for providing data for the review; and 4 anonymous referees for helpful comments that improved the manuscript. This study was funded by grants provided by DFG, Germany (Qu 148/1-ff) and NERC, UK (Grant-in-Kind EK 82-08/05), and approved by the Falkland Islands Government (Environmental Planning Office). 


\section{LITERATURE CITED}

Ainley DG, Ribic CA, Spear LB (1993) Species-habitat relationships among Antarctic seabirds - a function of physical or biological factors. Condor 95:806-816

Ainley DG, Ribic CA, Fraser WR (1994) Ecological structure among migrant and resident seabirds of the ScotiaWeddell confluence region. J Anim Ecol 63:347-364

Bearhop S, Waldron S, Votier SC, Furness RW (2002) Factors that influence assimilation rates and fractionation of nitrogen and carbon stable isotopes in avian blood and feathers. Physiol Biochem Zool 75(5):451-458

Bearhop S, Phillips RA, McGill R, Cherel Y, Dawson DA, Croxall JP (2006) Stable isotopes indicate sex-specific and long-term individual foraging specialisation in diving seabirds. Mar Ecol Prog Ser 311:157-164

Bocher P, Cherel Y, Labat JP, Mayzaud P, Razouls S, Jouventin P (2001) Amphipod-based food web: Themisto gaudichaudii caught in nets and by seabirds in Kerguelen waters, southern Indian Ocean. Mar Ecol Prog Ser 223: 261-276

Carabel S, Godinez-Dominguez E, Verisimo P, Fernandez L, Freire J (2006) An assessment of sample processing methods for stable isotope analyses of marine food webs. J Exp Mar Biol Ecol 336:254-261

Carboneras C (1992) Order Procellariiformes. In: del Hoyo J, Elliot A, Sargatal J (eds) Handbook of the birds of the world, Vol 1. Ostrich to ducks. Lynx Edicions, Barcelona, p $198-278$

> Cherel Y, Hobson KA (2007) Geographical variation in carbon stable isotope signatures of marine predators: a tool to investigate their foraging areas in the Southern Ocean. Mar Ecol Prog Ser 329:281-287

> Cherel Y, Bocher P, De Broyer C, Hobson KA (2002) Food and feeding ecology of the sympatric thin-billed Pachyptila belcheri and Antarctic P. desolata prions at Iles Kerguelen, Southern Indian Ocean. Mar Ecol Prog Ser 228: 263-281

> Cherel Y, Hobson KA, Weimerskirch H (2005a) Using stable isotopes to study resource acquisition and allocation in procellariiform seabirds. Oecologia 145:533-540

Cherel Y, Hobson KA, Bailleul FR, Groscolas R (2005b) Nutrition, physiology, and stable isotopes: new information from fasting and molting penguins. Ecology 86: 2881-2888

> Cherel Y, Phillips RA, Hobson KA, McGill R (2006) Stable isotope evidence of diverse species-specific and individual wintering strategies in seabirds. Biol Lett 2:301-303

Clark GS, Goodwin AJ, von Meyer AP (1984) Extension of the known range of some seabirds on the coast of southern Chile. Notornis 31:320-334

Cox JB (1980) Some remarks on the breeding distribution and taxonomy of the prions (Procellariidae: Pachyptila). J Aust Mus 18:91-121

Forero MG, Bortolotti GR, Hobson KA, Donazar JA, Bertelloti M, Blanco G (2004) High trophic overlap within the seabird community of Argentinean Patagonia: a multiscale approach. J Anim Ecol 73:789-801

Forero MG, Gonzalez-Solis J, Hobson KA, Doncazar JA, Bertellotti M, Blanco G, Bortolotti GR (2005) Stable isotopes reveal trophic segregation by sex and age in the southern giant petrel in two different food webs. Mar Ecol Prog Ser 296:107-113

Gladbach A, McGill RAR, Quillfeldt P (2007) Foraging areas of Wilson's storm-petrel Oceanites oceanicus in the breeding and inter-breeding period determined by stable isotope analysis. Polar Biol 30:1005-1012
Hobson KA (1995) Reconstructing avian diets using stable carbon and nitrogen isotope analysis of egg components: patterns of isotopic fractionation and turnover. Condor 97: $752-762$

Hobson KA (1999) Tracing origins and migration of wildlife using stable isotopes: a review. Oecologia 120:314-326

Hobson KA, Clark RG (1993) Turnover of ${ }^{13} \mathrm{C}$ cellular and plasma reactions of blood: implications for nondestructive sampling in avian dietry studies. Auk 110:638-641

Hobson KA, Welch HE (1992) Determination of trophic relationships within a high Arctic marine food web using $\delta^{13} \mathrm{C}$ and $\delta^{15} \mathrm{~N}$ analysis. Mar Ecol Prog Ser 84:9-18

Hobson KA, Sirois J, Gloutney ML (2000) Tracing nutrient allocation to reproduction with stable isotopes: a preliminary investigation using colonial waterbirds of Great Slave Lake. Auk 117:760-774

Hückstädt LA, Rojas CP, Antezana T (2007) Stable isotope analysis reveals pelagic foraging by the Southern sea lion in central Chile. J Exp Mar Biol Ecol 347:123-133

> Minagawa M, Wada E (1984) Stepwise enrichment of $\delta^{15} \mathrm{~N}$ along food chains: further evidence and the relation between $\delta^{15} \mathrm{~N}$ and animal age. Geochim Cosmochim Acta 48:1135-1140

Mizutani H, Fukuda M, Kabaya Y (1992) ${ }^{13} \mathrm{C}$ and ${ }^{15} \mathrm{~N}$ enrichment factors of feathers of 11 species of adult birds. Ecology 73:1391-1395

Neves T, Vooren CM, Bugoni L, Olmos F, Nascimento L (2006) Distribuição e abundância de aves marinhas no sudeste-sul do Brasil. In: Neves T, Bugoni L, RossiWongtschowski CLB (eds) Aves oceânicas e suas interações com a pesca na região Sudeste-Sul do Brasil. USP (Série Documentos Revizee: Score Sul), São Paulo, p 11-35

Nevoux M, Barbraud C (2006) Relationships between sea ice concentration, sea surface temperature and demographic traits of thin-billed prions. Polar Biol 29:445-453

> Nisbet ICT, Montoya JP, Burger J, Hatch JJ (2002) Use of stable isotopes to investigate individual differences in diets and mercury exposures among common terns Sterna hirundo in breeding and wintering grounds. Mar Ecol Prog Ser 242:267-274

Owens NJP (1988) Natural variation in ${ }^{15} \mathrm{~N}$ in the marine environment. Adv Mar Biol 24:389-451

Pinnegar JK, Polunin NVC (1999) Differential fractionation of $\delta^{13} \mathrm{C}$ and $\delta^{15} \mathrm{~N}$ among fish tissues: implications for the study of trophic interactions. Ecology 13:225-231

Podlesak DW, McWilliams SR, Hatch KA (2005) Stable isotopes in breath, blood, feces and feathers can indicate intra-individual changes in the diet of migratory songbirds. Oecologia 142(4):501-510

Post DM (2002) Using stable isotopes to estimate trophic position: models, methods, and assumptions. Ecology 83: 703-718

> Quillfeldt P, Masello JF, Strange IJ (2003) Breeding biology of the thin-billed prion Pachyptila belcheri at New Island, Falkland Islands, in the poor season 2002/2003: egg desertion, breeding success and chick provisioning. Polar Biol 26:746-752

Quillfeldt P, McGill RAR, Furness RW (2005) Diet and foraging areas of Southern Ocean seabirds and their prey inferred from stable isotopes: review and case study of Wilson's storm-petrel. Mar Ecol Prog Ser 295:295-304

> Quillfeldt P, Masello JF, Strange IJ, Buchanan KL (2006) Begging and provisioning of thin-billed prions Pachyptila belcheri is related to testosterone and corticosterone. Anim Behav 71:1359-1369

Quillfeldt P, Strange IJ, Masello JF (2007a) Sea surface 
temperatures and behavioural buffering capacity in thinbilled prions Pachyptila belcheri: breeding success, provisioning and chick begging. J Avian Biol 38:298-308

Quillfeldt P, Strange IJ, Segelbacher G, Masello JF (2007b) Male and female contributions to provisioning rates of thin-billed prions Pachyptila belcheri in the South Atlantic. J Ornithol 148:367-372

Quillfeldt P, Poisbleau M, Chastel O, Masello JF (2007c) Corticosterone in thin-billed prion Pachyptila belcheri chicks: diel rhythm, timing of fledging and nutritional stress. Naturwissenschaften 94:919-925

Rubenstein DR, Hobson KA (2004) From birds to butterflies:

Editorial responsibility: Rory Wilson,

Swansea, UK animal movement patterns and stable isotopes. Trends Ecol Evol 19:256-263

Strange IJ (1980) The thin-billed prion Pachyptila belcheri at New Island, Falkland Islands. Gerfaut 70:411-445

Thompson KR (1989) An assessment of the potential for competition between seabirds and fisheries in the Falkland Islands. Falkland Islands Foundation Project Report, Falkland Islands Foundation, Brighton

White RW, Reid JB, Black AD, Gillon KW (1999) Seabird and marine mammal dispersion in the waters around the Falkland Islands 1998-1999. Joint Nature Conservation Commitee, Peterborough

Submitted: January 4, 2008; Accepted: September 21, 2008 Proofs received from author(s): December 5, 2008 